\title{
PENGARUH BACK MASSAGE TERHADAP INTENSITAS NYERI PUNGGUNG PENYADAP KARET DI DESA LUBUK KETEPENG KECAMATAN JEJAWI KABUPATEN OGAN KOMERING ILIR
}

\author{
Mujahidin \\ Program Studi Ilmu Keperawatan STIK Bina Husada Palembang \\ Jl. Syech Abdul Somad No 28 Kelurahan 22 Ilir Palembang Telpon 0711365533 \\ e-mail : mujahidinnsmkes@gmail.com
}

\begin{abstract}
Abstrak
Salah satu pekerjaan utama dari warga Desa Lubuk Ketepeng selain bertani padi juga adalah sebagai penyadap getah karet. Pekerjaan ini merupakan salah satu pekerjaan yang dilakukan oleh sebagian besar masyarakat Desa sehari hari. Kegiatan menyadap getah karet yang dikukan ini sering kali menimbulkan permasalahan nyeri pada area punggung dikarenakan dalam menyadap karet warga melakukannya secara manual dengan alat yang disebut warga sebagai pahat dan dikerjakan dengan menggunakan tangan. Penelitian ini bertujuan untuk mengetahui pengaruh Back Massage terhadap intensitas nyeri punggung penyadap karet di Desa Lubuk Ketepeng Kecamatan Jejawi Kabupaten Ogan Komering Ilir Provinsi Sumatera Selatan. Metode penelitian adalah Quasy Eksperimen pre test post test design. Pengambilan sampel dengan tehnik purposive sampling dengan jumlah sampel sebanyak 40 orang. Analisis data menggunakan Uji Wilcoxon. Hasil penelitian diketahui sebelum diberikan Back Massage sebanyak 40 orang sampel mengalami nyeri punggung intensitas sedang dengan skala nyeri 4 7, dan setelah diberikan Back Massage sebanyak 40 orang sampel mengalami penurunan intensitas nyeri punggung menjadi nyeri ringan dengan skala nyeri 1-3. Hasil uji Wilcoxon didapat nilai p value 0,000. Berdasarkan hasil tersebut maka disimpulkan bahwa terdapat pengaruh yang signifikan dari Back Massage terhadap intensitas nyeri punggung penyadap karet di Desa Lubuk Ketepeng Kecamatan Jejawi Kabupaten Ogan Komering Ilir.
\end{abstract}

Kata Kunci : Nyeri Punggung Penyadap Karet, Back Massage

\begin{abstract}
One of the main jobs of the residents of Lubuk Ketepeng Village is tapping rubber sap. This work is one of the day-to-day jobs carried out by most of the village community. The activity of tapping rubber latex that is claimed often causes pain problems in the back area because in tapping rubber the residents do it manually with a tool called a chisel and is done by hand. This study aims to determine the effect of back massage on the intensity of back pain of rubber tappers in Lubuk Ketepeng Village, Jejawi District, Ogan Komering Ilir Regency, South Sumatra Province. The research method is Quasy Experiment pre test post test design. Sampling with purposive sampling technique with a sample size of 40 people. Data analysis using the Wilcoxon Test. The results showed that before giving back massage as many as 40 samples experienced moderate intensity back pain with a pain scale of 4-7, and after being given Back Massage as many as 40 samples experienced a decrease in back pain intensity to mild pain with a pain scale of 1-3. The Wilcoxon test results obtained a p value of 0,000. Based on these results, it was concluded that there was a significant effect of Back Massage on the intensity of back pain in the rubber tappers in Lubuk Ketepeng Village, Jejawi District, Ogan Komering Ilir Regency.
\end{abstract}

Keywords: Rubber Tappers Back Pain, Back Massage

Jurnal Kesehatan dan Pembangunan, Vol. 11, No. 22, Juli 2021 


\section{PENDAHULUAN}

Menyadap karet merupakan salah satu pekerjaan utama yang dilakukan sebagian besar warga Desa Lubuk Ketepeng selain bertani padi secara turun temurun. Menyadap karet ini menjadi sumber utama kehidupan mereka. Tersedianya lahan dan didukung dengan kondisi tanah yang memang cocok untuk ditanami karet menjadikan bertanam karet ini menjadi salah satu usaha favorit yang dilakukan oleh warga Desa

Tahapan yang dilakukan dalam proses menanam karet ini cukup panjang. Dimulai dari menyiapkan lahan, menyiapkan bibit, proses menanam, merawat sampai paling tidak usia batang karet berumur 7 tahun barulah bisa dilakukan penyadapan.

Menyadap karet ini dilakukan dengan cara memberikan perlukaan atau penyayatan pada kulit batang karet dengan menggunakan alat yang disebut warga sebagai pahat. Pahat ini disayatkan pada kulit batang karet dengan menggunakan kekuatan tangan dan punggung yang nantinya akan keluarlah getah karet. Getah karet inilah yang nantinya dijual dan akan menghasilkan pemasukan bagi penyadap karet. Menyadap karet ini seringkali menimbulkan permasalahan kesehatan terutama yang paling umum terjadi adalah mengalami nyeri punggung bagian atas.

Ada beberapa cara yang biasanya dilakukan oleh penyadap karet untuk mengatasi permasalahan nyeri punggung ini seperti mengoleskan minyak gosok yang menimbulkan sensasi hangat di kulit dan terkadang juga petani menuju ke layanan kesehatan seperti puskesmas untuk berobat, namun tak sedikit juga yang membiarkan karna dianggap sudah biasa dan nantinya juga akan hilang sendiri.

Di keperawatan dikenal beberapa tehnik yang bisa digunakan untuk mengatasi permasalahan nyeri seperti yang paling sering didengar adalah dengan menggunakan tehnik distraksi dan relaksasi.

Beberapa penelitian tentang nyeri punggung dan tehnik manajemen nyeri telah banyak dilakukan. Misalnya penelitian Saravana Kumar, Kate Beaton, Tricia Hughes tahun 2013 dengan judul The effectiveness of message therapy for the treatment of non spesific low back pain. Hasil penelitian menemukan beberapa bukti tentang keefektifan terapi pijat untuk pengobatan nyeri punggung bawah non spesifik.

Ardi Utomo dan B.M. Wara Kushartanti tahun 2019 juga pernah melakukan penelitian tentang efektivitas massage frirage dan kombinasi back massage stretching untuk penyembuhan nyeri pinggang. Hasil penelitiannya menunjukkan bahwa massage frirage berdampak baik pada penyembuhan nyeri punggung. Penelitian lain juga pernah dilakukan oleh Seung-Kook Kim, Aran Min, Chuljin Jeon, Taeyun Kim, Soohyun Cho, Su-Chan Lee, Choon-Key Lee tahun 2020 dengan judul penelitiannya Clinical outcomes and cost-effectiveness of massage chair therapy versus basic physiotherapy in lower back pain patients. Hasil penelitian menunjukkan bahwa penggunaan kursi pijat merupakan pengobatan yang menjanjikan untuk pengendalian nyeri.

Ni PP Kusuma Dewi, I Nyoman Sutresna, I Made Dwie Pradnya Susila pada tahun 2017 juga pernah meneliti tentang pengaruh back massage terhadap tingkat nyeri tulang belakang pada kelompok tani semangka mertha abadi di Desa Yeh Sumbul. Hasil penelitian mereka mengungkapkan bahwa pijat punggung memberikan pengaruh yang cukup signifikan terhadap tingkat nyeri punggung bawah.

Cherkin DC, Sherman KJ, Kahn J et al tahun 2012 juga pernah melakukan penelitian yang mirip seperti yang dilakukan oleh Ni PP Kusuma Dewi dkk, hasilnya juga menunjukkan hasil yang cukup signifikan dalam mengurangi rasa nyeri punggung 
bawah dan masih banyak lagi penelitian penelitian lain tentang massage dan pengaruhnya terhadap intensitas nyeri seperti pada nyeri haid osteoartritis (Mira Triharini dkk), nyeri post operasi appendiksitis (Tiarnida dkk 2018), hal serupa juga pernah dilakukan oleh Irawan Wirya, Margareth Duma Sari tahun 2013 yang meneliti Pengaruh pemberian massase punggung dan tehnik relaksasi nafas dalam terhadap penurunan intensitas nyeri pada pasien post appendiktomi. Penelitian tentang massage dan nyeri post operasi laparatomi dilakukan oleh Rizky T D tahun 2019.

Penelitian tentang massage dan nyeri pada proses persalinan pernah dilakukan oleh Elly Wahyuni, Reka Lagora Marsofely, Chyntamie Wulandari tahun 2018. Oleh Liva Maita 2016. Oleh MS. Jeelani Saima Habeeb and Dr. Manju Chhughani dan oleh Deepika Sethi, Seema Barnabas tahun 2017.

Zuliani pada tahun 2013 meneliti tentang nyeri haid. Fatemeh Muhaddes, Narges Ghaderi Ehsanpour, Tahereh Najafi Ghezeljeh tahun 2018 meneliti tentang massage dan tingkat kecemasan pada pasien gagal jantung. Muhammad Ardi, Dyah Ekowatiningsih tahun 2017 meneliti tentang efektivitas slow stroke back massage dalam meningkatkan relaksasi pasien stroke. Kemudian Amol Sable, Thangaraj Sivabalan, Akshaya Narayan Shetti. Juga pernah meneliti tentang efektivitas pijat punggung terhadap pasien dengan gagal jantung kongestif.

Sebelumnya peneliti juga sudah pernah melakukan penelitian tentang pengaruh Back Massage terhadap intensitas nyeri punggung pada petani padi di Desa Lubuk Ketepeng. Hasil penelitian diketahui jika terdapat pengaruh yang cukup signifikan dari pemberian Back Massage terhadap penurunan intensitas nyeri punggung patani padi

Dari beberapa penelitian penelitian yang telah dikemukakan diatas, sudah cukup banyak yang mengkaji tentang nyeri punggung dan manajemen nyeri yang digunakan. Dari penelitian yang peneliti juga pernah lakukan diketahui jika Back Massage memberikan pengaruh, namun dalam kesempatan ini peneliti ingin melihat bagimana pengaruh Back Massage terhadap intensitas nyeri punggung yang dilakukan pada penyadap karet di Desa Lubuk Ketepeng Kecamatan Jejawi Kabupaten Ogan Komering Ilir dan dilaksanakan dengan berpedoman pada protokol kesehatan yang telah dihimbau oleh Pemerintah sehingga resiko penyebaran dan penularan virus covid 19 dalam kegiatan penelitian ini diharap dapat bisa lebih diminimalisir.

\section{METODE}

\section{Jenis Penelitian}

Penelitian ini merupakan penelitian Quasy Eksperimen pre test post test design.

\section{Waktu dan Tempat Penelitian}

Penelitian ini dilaksanakan pada bulan Maret 2021 bertempat di Desa Lubuk Ketepeng Kecamatan Jejawi Kabupaten Ogan Komering Ilir.

\section{Subyek Penelitian}

Populasi pada penelitian ini adalah seluruh penyadap karet di Desa Lubuk Ketepeng Kecamatan Jejawi Kabupaten Ogan Komering Ilir sedangkan sampel adalah petani penyadap karet berjumlah 40 orang yang dipilih dengan tehnik purposive sampling serta memenuhi kriteria yang telah ditentukan yaitu merupakan penyadap karet, bersedia berpartisipasi dalam penelitian dan mengalami nyeri punggung.

\section{Prosedur Pengumpulan Data}

Alat dan Bahan Yang Digunakan terdiri dari formulir Check List dan penggunaan aplikasi zoom meeting ,Whatshap, telepon dan SMS untuk berkomunikasi.

Cara kerja penelitian atau proses pelaksanaan penelitian secara langsung dan bertemu dengan sampel penelitian di masa pandemi covid 19 sekarang ini akan 
berpotensi terhadap penyebaran dan penularan virus covid 19. Oleh karna itu dalam pelaksanaan penelitian kali ini, proses tahapan penelitian lebih banyak dilaksanakan secara online. Dimulai dari proses menghubungi dan meminta kesediaan sampel untuk berpartisipasi dalam proses penelitian yang dihungungi dengan telepon/pesan whatshap. Kemudian setelah semua sampel terkumpul dan bersedia berpastisipasi peneliti menjelaskan tentang tehnis pelaksanaan penelitian, bagaimana cara pengisian formulir cek list, cara menentukan intensitas nyeri dan bagaimana melakukan back massage dengan menggunakan video yang selanjutnya video tersebut dikirimkan dan ditonton oleh sampel penelitian. Proses penelitian dimulai dengan mengirimkan cek list intensitas nyeri sebelum dan sesudah dilakukan back massage ke sampel penelitian, setelah itu sampel diminta untuk melakukan gerakan gerakan back massage yang sebelumnya telah dipelajari melalui video yang peneliti kirim. Setelah melakukan back massage peneliti meminta sampel untuk mengisi kembali intensitas nyeri pada formulir cek list yang telah diberikan dan mengirimkannya kembali ke peneliti melalui pesan whatshap.

\section{Etika Penelitian}

a) Sampel yang akan berpartisipasi terlebih dahulu diminta kesediaannya untuk berpartisipasi, tanpa paksaan yang diminta untuk menandatangani surat kesediaan berpartisipasi dalam proses penelitian.

b) Indentitas sampel dijamin kerahasiaanya oleh peneliti.

c) Photo dokumentasi hanya digunakan sebagai data dalam penelitian, tidak akan terpublikasi/terekspose selaian dari kepentingan penelitian

\section{Tehnik Analisis Data}

Setelah semua data terkumpul selanjutnya di entry dan diolah dengan menggunakan program SPSS. Pertama yang dilakukan adalah menilai sebaran data apakah berdistribusi normal atau tidak dikarenakan uji hipotesis yang akan digunakan adalah uji $\mathrm{T}$ Berpasangan yang mensyaratkan sebaran data harus berdistribusi normal. Setelah dilakukan uji normalitas diketahui jika sebaran data tidak berdistribusi normal sehingga uji hipotesis yang digunakan dalam menganalisis adalah uji alternatif dari uji T Berpasangan yaitu uji Wilcoxone.

\section{HASIL PENELITIAN DAN PEMBAHASAN}

\section{Tabel 1}

Umur Sampel Penelitian

\begin{tabular}{ccc}
\hline Umur & Frekuensi & Persen \\
\hline 20 & 1 & 5.0 \\
18 & 2 & 2.5 \\
30 & 1 & 2.5 \\
27 & 3 & 7.5 \\
29 & 1 & 2.5 \\
25 & 1 & 2.5 \\
31 & 1 & 2.5 \\
33 & 2 & 5.0 \\
34 & 1 & 2.5 \\
35 & 4 & 10.0 \\
36 & 1 & 2.5 \\
37 & 2 & 5.0 \\
38 & 2 & 5.0 \\
39 & 1 & 2.5 \\
42 & 1 & 2.5 \\
43 & 2 & 5.0 \\
46 & 2 & 5.0 \\
48 & 2 & 5.0 \\
49 & 3 & 7.5 \\
50 & 2 & 5.0 \\
52 & 1 & 2.5 \\
58 & 2 & 5.0 \\
59 & 1 & 2.5 \\
60 & 1 & 2.5 \\
\hline Total & $\mathbf{4 0}$ & $\mathbf{1 0 0 . 0}$ \\
\hline & & \\
\hline
\end{tabular}

Tabel 2

Jenis Kelamin Sampel Penelitian

Jenis Kelamin Frekuensi Persen 


\begin{tabular}{|c|c|c|}
\hline Laki Laki & 28 & 75.5 \\
\hline Perempuan & 12 & 24.5 \\
\hline Total & 40 & 100.0 \\
\hline \multicolumn{3}{|c|}{$\begin{array}{c}\text { Tabel } 3 \\
\text { Status Pernikahan }\end{array}$} \\
\hline $\begin{array}{c}\text { Status } \\
\text { Pernikahan } \\
\end{array}$ & Frekuensi & Persen \\
\hline Belum Menikah & 5 & 15.5 \\
\hline Duda & 1 & 2.5 \\
\hline Janda & 2 & 5.0 \\
\hline Menikah & 32 & 77.0 \\
\hline Total & 40 & 100.0 \\
\hline
\end{tabular}

Tabel 4 Jumlah Anggota Keluarga

\begin{tabular}{ccc}
\hline $\begin{array}{c}\text { Jumlah Anggota } \\
\text { Keluarga }\end{array}$ & Frekuensi & Persen \\
\hline 1 & 2 & 5.0 \\
2 & 1 & 2.5 \\
3 & 7 & 17.5 \\
4 & 16 & 40.0 \\
5 & 10 & 25.0 \\
6 & 4 & 10.0 \\
\hline Total & $\mathbf{4 0}$ & $\mathbf{1 0 0 . 0}$ \\
\hline
\end{tabular}

Tabel 5

Status Pekerjaan

\begin{tabular}{lcc}
\hline $\begin{array}{l}\text { Status } \\
\text { Pekerjaan }\end{array}$ & Frekuensi & Persen \\
\hline Penyadap Karet & 40 & 100.0 \\
\hline Total & $\mathbf{4 0}$ & $\mathbf{1 0 0 . 0}$ \\
\hline
\end{tabular}

Tabel 6

Nyeri Sebelum diberikan Back Massage

\begin{tabular}{lcc}
\hline Nyeri Sebelum & Frekuensi & Persen \\
\hline Nyeri Ringan & 0 & 0 \\
\hline Nyeri Sedang & 40 & 100.0 \\
\hline Nyeri Berat & 0 & 0 \\
\hline Total & $\mathbf{4 0}$ & $\mathbf{1 0 0 . 0}$ \\
\hline
\end{tabular}

Tabel 7

Nyeri Sesudah diberikan Back Massage

\begin{tabular}{ccc}
\hline Nyeri Sebelum & Frekuensi & Persen \\
\hline Nyeri Ringan & 40 & 100.0 \\
\hline
\end{tabular}

\begin{tabular}{lcc} 
Nyeri Sedang & 0 & 0 \\
\hline Nyeri Berat & 0 & 0 \\
\hline Total & $\mathbf{4 0}$ & $\mathbf{1 0 0 . 0}$
\end{tabular}

Tabel 8

Pengaruh Back Massage Terhadap Intensitas Nyeri Punggung Penyadap Karet

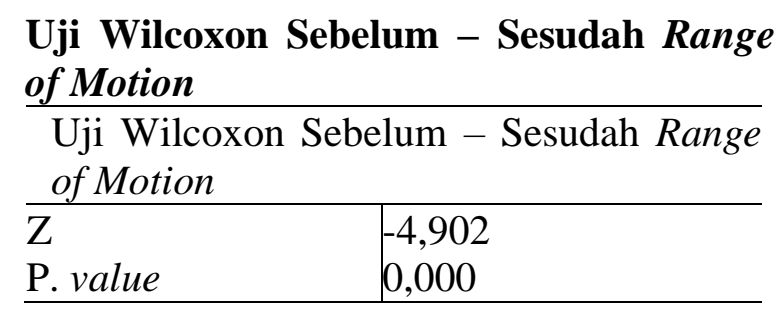

Tabel 1 diatas menunjukkan karakteristik umur sampel penelitian yang bervariasi mulai dari paling muda umur 18 tahun dan paling tua umur 60 tahun. Di tabel 2 jenis kelamin sampel penelitian yang terdiri dari 31 orang sampel dengan jenis kelamin laki laki (77.5\%) dan sebanyak 9 orang sampel dengan jenis kelamin perempuan (22.5\%). Pada tabel 3 status pernikahan sampel yaitu sebanyak 30 orang sampel $(75 \%)$ sudah menikah, sebanyak 7 orang sampel (17.5\%) belum menikah, sebanyak 2 orang sampel (5\%) janda dan 1 orang sampel (2.5\%) dengan status duda.

Tabel 4 jumlah anggota keluarga, diketahui dari 40 sampel yang berpartisipasi sebanyak 16 orang sampel (40.0\%) memiliki 4 anggota keluarga, 10 orang sampel (25\%) memiliki 5 anggota keluarga, 7 orang sampel (17.5\%) memiliki 3 orang anggota keluarga, 4 orang sampel $(10.0 \%)$ memiliki 6 orang anggota keluarga, 2 orang sampel $(5.0 \%)$ memiliki 1 orang keluarga dan 1 orang sampel (2.5\%) memiliki 2 orang keluarga.

Tabel 5 status pekerjaan, semua sampel yang berpartisipasi bekerja sebagai penyadap karet di Desa Lubuk Ketepeng Kecamatan Jejawi Kabupaten Ogan Komering Ilir.

Tabel 6 intensitas nyeri sebelum 
diberikan Back Massage sebanyak 40 orang sampel mengalami nyeri punggung dengan intensitas nyeri sedang dan tabel 7 intensitas nyeri setelah diberikan Back Massage sebanyak 40 orang sampel mengalami penurunan intensitas nyeri punggung menjadi nyeri ringan.

Tabel 8 hasil analisis dengan menggunakan uji wilcoxone diketahui jika nilai $p$ value 0.000 yang berarti menunjukkan bahwa terdapat pengaruh signifikan Back Massage terhadap penurunan intensitas nyeri punggung penyadap karet di Desa Lubuk Ketepeng.

\section{PEMBAHASAN}

Hasil penelitian yang telah disampaikan diatas selaras dengan beberapa penelitian penelitian yang telah dilakukan sebelumnya seperti penelitian yang pernah dilakukan oleh Saravana Kumar, Kate Beaton, Tricia Hughes tahun 2013 dengan judul penelitiannya The effectiveness of message therapy for the treatment of non spesific low back pain. Hasil penelitian mereka menemukan beberapa bukti tentang keefektifan terapi pijat untuk pengobatan nyeri punggung bawah non spesifik.

Ardi Utomo dan B.M. Wara Kushartanti tahun 2019 juga pernah melakukan penelitian tentang efektivitas massage frirage dan kombinasi back massage stretching untuk penyembuhan nyeri pinggang. Hasil penelitiannya menunjukkan bahwa massage frirage berdampak baik pada penyembuhan nyeri punggung.

Penelitian lain juga pernah dilakukan oleh Seung-Kook Kim, Aran Min, Chuljin Jeon, Taeyun Kim, Soohyun Cho, Su-Chan Lee, Choon-Key Lee pada tahun 2020 dengan judul penelitiannya Clinical outcomes and cost-effectiveness of massage chair therapy versus basic physiotherapy in lower back pain patients. Hasil penelitian mereka menunjukkan bahwa penggunaan kursi pijat merupakan pengobatan yang menjanjikan untuk pengendalian nyeri.

Ni PP Kusuma Dewi, I Nyoman Sutresna, I Made Dwie Pradnya Susila pada tahun 2017 juga pernah meneliti tentang pengaruh back massage terhadap tingkat nyeri tulang belakang pada kelompok tani semangka mertha abadi di Desa Yeh Sumbul. Hasil penelitian mereka mengungkapkan bahwa pijat punggung memberikan pengaruh yang cukup signifikan terhadap tingkat nyeri punggung bawah.

Cherkin DC, Sherman KJ, Kahn J et al tahun 2012 juga pernah melakukan penelitian yang mirip seperti yang dilakukan oleh Ni PP Kusuma Dewi dkk, hasilnya juga menunjukkan hasil yang cukup signifikan dalam mengurangi rasa nyeri punggung bawah.

Dari hasil penelitian yang telah dilakukan oleh peneliti dan juga melihat hasil hasil penelitian yang pernah dilakukan sebelumnya peneliti menarik kesimpulan bahwa back massage memang baik digunakan sebagai salah satu pilihan alternatif untuk mengurangi rasa nyeri khusunya nyeri yang terjadi pada area punggung belakang. back massage yang dilakukan dapat membantu lancarnya proses sirkulasi darah didalam jaringan sehingga kebutuhan jaringan akan oksigen dapat tercukupi dengan baik.

\section{KESIMPULAN}

Dari hasil penelitian yang telah dlakukan maka disimpulkan bahwa terdapat 40 orang sampel $(100 \%)$ megalami nyeri punggung dengan intensitas nyeri sedang sebelum diberikan Back Massage, dan terdapat 40 orang sampel $(100 \%)$ megalami nyeri punggung dengan intensitas nyeri ringan setelah diberikan Back Massage.

Hasil analisis dengan menggunakan uji wilcoxone didapatkan nilai $p$ value 0.000 , hal ini menunjukkan bahwa terdapat pengaruh yang cukup signifikan dari Back Massage terhadap penurunan intensitas 
nyeri punggung pada penyadap karet di Desa Lubuk Ketepeng Kecamatan Jejawi Kabupaten Ogan Komering Ilir.

\section{SARAN}

Back Massage atau pijat punggung dapat dilakukan oleh penyadap karet yang mengalami nyeri punggung. Oleh karna itu, penggunaan obat obatan untuk menurunkan rasa nyeri tersebut dapat dikurangi dan dapat diganti dengan menggunakan Back Massage.

\section{DAFTAR PUSTAKA}

Saravana Kumar, Kate Beaton, Tricia

Hughes (2013) The effectiveness of message therapy for the treatment of non spesific low back pain ; a systematic review of systematic reviews. International Journal of General Medicine

Ardi Utomo, B.M. Wara Kushartanti (2019). Efektivitas massage frirage dan kombinasi back massagestretching untuk penyembuhan nyeri pinggang.

Jurnal Keolahragaan Volume 7 Nomor 1

Seung-Kook Kim, Aran Min, Chuljin Jeon, Taeyun Kim, Soohyun Cho, Su-Chan

Lee, Choon-Key Lee (2020). Clinical outcomes and costeffectiveness of massage chair therapy versus basic physiotherapy in lower back pain patients : A randomized controlled trial. National Library of Medicine

Ni PP Kusuma Dewi, I Nyoman

Sutresna, I Made Dwie Pradnya Susila (2017). Pengaruh Back Massage terhadap tingkat nyeri low back pain pada kelompok tani semangka mertha abadi di Desa Yeh Sumbul. Journal Centre of Research
Publication in Midwifery and Nursing.

Cherkin DC, Sherman KJ, Kahn J et al (2012). Massage shown to benefit patients with choronic low back pain. Journal of the American Osteopathic Association

Syahrul, Naimah Hayati (2018).

Pengaruh stimulus kutaneus

slow stroke back massage terhadap intensitas nyeri pada penderita low back pain (LBP) di wilayah kerja Puskemas Kurai Taji Kecamatan Parimana Selatan. Human Care Journal Volume 3 Nomor 3. ISSN 2528-66510

Mira Triharini, Mardiyah, Setho

Hadisuyatmana (2010). Cutaneus stimulation :

Slow stroke back massage reduces the intensity of osteoartritis pain of elderly. Jurnal Ners Volume 5 Nomor 1 e-ISSN 2502-5791

Tiarnida Nababan, Karmila Br Kaban,

Ricky Rahmat Ndruru (2019). Pengaruh tehnik back massage (masase punggung) terhadap penurunan intensitas nyeri pada pasien post operasi appendiksitis di RSU Royal Prima Medan. Jurnal Keperawatan Priority Volume 2 Nomor 2 ISSN 2614-4719

Rizky Tiara Damayanti, Isnaeni, Joko

Wiyono (2019). Differences pain intensity between back massage therapy and finger hold relaxation in patien post laparatomi. Jurnal Keperawatan Terapan Volume 5 Nomor 1

Irawan Wirya, Margareth Duma Sari (2013). Pengaruh pemberian massase punggung dan tehnik relaksasi nafas dalam terhadap penurunan intensitas nyeri pada pasien post appendiktomi di zaal $C$ RS HKBP Balige. Jurnal Keperawatan HKBP Balige Volume 1 Nomor 1 
Elly Wahyuni, Reka Lagora Marsofely, Chyntamie Wulandari (2018). Deep back massage effect on the reduction of active phase 1 labor pain at the Curup Public Hospital Indonesia. International Journal of Science : Basic and Applied Research (IJBAR) Volume 42 Nomor 4

Liva Maita (2016) Pengaruh Deep Back Massage Terhadap Penurunan Nyeri Persalinan. Journal.unusa.ac.id

MS. Jeelani Saima Habeeb and Dr.

Manju Chhughani. A Study to asses the effectivenessof back massage on pain among primigravida mother during first stage of labour. International Journal of Current Research

Deepika Sethi, Seema Barnabas (2017).

A pre-eksperimental study to evaluate the effectiveness of back massage among pregnant women in first stage of labour paints admitted in labour room of selected hospital, Ludhiana, Punjab, India. International Journal of Reproduction, Contraception, Obstetrics and Gynecology Volume 6 Nomor 1 ISSN : 2320-1789

Zuliani (2013). Pengaruh stimulasi kutaneus (Slow stroke back massage) Terhadap penurunan nyeri haid (dismenorea). Journal Eduhealth Volume

3 Nomor 2

Fatemeh Muhaddes, Narges Ghaderi

Ehsanpour, Tahereh Najafi Ghezeljeh (2018). The effect of slow stroke back massage on anxiety in female patients with heart failure. Researchgate.net

Muhammad Ardi, Dyah Ekowatiningsih (2017). Efektivitas slow stroke back massage dalam meningkatkan relaksasi pasien stroke di Rumah Sakit Umum Daerah Kota Makasar. Media Kesehatan Politeknik
Kesehatan Makasar Volume 12 Nomor 1 ISSN : 2549-0567

Maria Anita Yusiana, Heru Suwardianto (2014). The effectiveness of deep breathing and slow stroke back massage to decrease the blood pressure on patients with hypertention. Indonesia Nursing Journal of Education and Clinic (INJEC) Volume 1 Nomor 1 ISSN : 2527-8819

Mahadeo B Shinde, Shabana Ajum (2014). Effectiveness of slow back massage on quality of sleep among ICU patient's. International Journal of Science and Research (IJSR) ISSN : 2319-7064

Amol Sable, Thangaraj Sivabalan, Akshaya Narayan Shetti. Effectiveness of back massage on sleep pattern among patients with congestive cardiac failure. National Library of Medicine. pubmed.ncbi.nlm.nih.gov respiratory.unsri.ac.id

Hildani (2012). Nyeri punggung. Eprints.ulm.ac.id 